\title{
Effects of sludge pretreatment on sludge reduction in a lab-scale anaerobic/anoxic/oxic system treating domestic wastewater
}

\author{
D. K. Uan · I. T. Yeom $\cdot$ P. Arulazhagan • \\ J. Rajesh Banu
}

Received: 9 January 2012/ Accepted: 25 September 2012/Published online: 23 November 2012

(c) CEERS, IAU 2012

\begin{abstract}
Excess sludge disposal is one of the serious challenges in biological wastewater treatment. Reduction of sludge production would be an ideal way to solve sludgeassociated problems rather than the post-treatment of the sludge produced. In this study, a new wastewater treatment process combining anaerobic/anoxic/oxic system with thermochemical sludge pretreatment was tested in a laboratory scale experiment. In this study, the effects of the sludge pretreatment on the excess sludge production in anaerobic/anoxic/oxic were investigated. The system was operated in two Runs (1 and 2). In Run 1, the system was operated as a reference and in Run 2, a part of the mixed liquid was pretreated thermochemically and was returned to the bioreactor. The average solubilization efficiency of pretreated sludge was found to be about $35 \%$ during the study period of 220 days. Sludge production rate in Run 2 was less than that in Run 1 by about $52 \%$. Total phosphorous was removed by enhanced biological phosphorous removal with the removal efficiency of $83-87 \%$ and
\end{abstract}

D. K. Uan

Institute for Environmental Science and Technology,

Hanoi University of Science and Technology, Hanoi, Vietnam

D. K. Uan · I. T. Yeom

Department of Civil and Environmental Engineering,

Sungkyunkwan University, Suwon 440-746, Korea

P. Arulazhagan

Centre of Excellence in Environmental Studies,

King Abdulaziz University, Jeddah 21589, Saudi Arabia

e-mail: arulazhagan_p@yahoo.co.in

J. Rajesh Banu ( $\square)$

Department of Civil Engineering, Anna University Tirunelveli,

Tirunelveli, Tamil Nadu, India

e-mail: rajeshces@gmail.com
81-83\% for Run 1 and Run 2, respectively. Total nitrogen removal in Run 2 (79-82 \%) was slightly higher than that in Run 1 (68-75\%). The mixed liquor suspended solids/ mixed liquor volatile suspended solids ratio was identical after both runs in the range $78-83 \%$. The effluent water qualities were not significantly affected when operated with thermochemical pretreatment at $\mathrm{pH} 11$ and $60{ }^{\circ} \mathrm{C}$ for $3 \mathrm{~h}$ during 7 months. From the present study it is concluded that thermochemical sludge pretreatment of anaerobic/anoxic/ oxic process plays an important role in reduction of sludge production.

Keywords Anaerobic/anoxic/oxic reactor - Biological nutrient removal $\cdot$ Sludge reduction $\cdot$ Thermochemical pretreatment

\section{Introduction}

Wastewater containing excessive nitrogen $(\mathrm{N})$ and phosphorous (P) may lead to serious environmental problems such as eutrophication when discharged into receiving waters (Yeoman et al. 1988; Lee et al. 2003). So, it is necessary to reduce the concentration of these nutrients before discharging to prevent the algal bloom. The most commonly used process is a single-sludge suspended growth system incorporating anaerobic/anoxic/oxic (AAO) stages in sequence (Ma et al. 2005). During operation, a considerable volume of sludge should be withdrawn in order to maintain appropriate level of biomass concentration in the system (Oh et al. 2007). Treatment and disposal of excess sludge accounts for about $50-60 \%$ of the total operational cost of wastewater treatment plants (Davis and Hall 1997; Spellman 1997). The conventional disposal methods such as landfill may cause secondary pollution 
problems and are strictly regulated in many countries (Liu and Tay 2001). Hence, excess sludge reduction has been found to be one of the major challenges in this field. Several methods to pretreat waste sludge were employed to accelerate the solubilization of sludge, such as thermal pretreatment (Pinnekamp 1989; Climent et al. 2007), chemical pretreatment (Rajan et al. 1989; Ray et al. 1990; Carballa et al. 2006; Rajesh et al. 2012); and thermochemical pretreatment (Stuckey and McCarty 1984; Tanaka et al. 1997).

Among these disintegration techniques, thermochemical hydrolysis using sodium hydroxide was found to be the most efficient in inducing cell lysis (Novelli et al. 1995). When compared with other pretreatment methods, alkaline treatment was more efficient because of a simple device, convenience of operation, and high efficiency (Navia et al. 2002; Kim et al. 2003; Neyens et al. 2004; Carballa et al. 2006). The alkaline treatment destroys floc structures and cell walls by hydroxyl anions. Due to extremely high $\mathrm{pH}$, the protein loses its natural shape, saponification of lipids takes place, and hydrolysis of ribonucleic acid (RNA) takes place. Chemical degradation and ionization of the hydroxyl groups lead to extensive swelling and subsequent solubilization of gels in sludge (Neyens et al. 2004). After the destruction of extracellular polymer substances (EPS), the cell walls, being exposed to a high $\mathrm{pH}$, which cannot withstand the appropriate turgor pressure, leads to disruption of cells and release of intracellular substances (Erdincler and Vesilind 2000). Thermal pretreatment was studied using a wide range of temperatures ranging from 60 to $270{ }^{\circ} \mathrm{C}$. Temperatures over $200{ }^{\circ} \mathrm{C}$ have been found responsible for refractory compound formation (Muller 2000). The most common treatment temperatures are between 60 and $180{ }^{\circ} \mathrm{C}$. Treatments applied at temperatures below $100{ }^{\circ} \mathrm{C}$ are considered as low temperature thermal treatments (Gavala et al. 2003).

To improve the efficiency of sludge reduction, researchers used different pretreatment methods such as ozonation (Yan et al. 2009), microwave (Eskicioglu et al. 2008) and ultrasonication ( $\mathrm{Li}$ et al. 2009; Salsabil et al. 2009). According to previous reports, combinations of different pretreatments that accelerated the sludge reduction process were as follows: Bernal-Martinez et al. (2005) reported sludge reduction using the combination of ozonation and anaerobic digestion where ozonation of anaerobically digested sludge improved the PAH (polyaromatic hydrocarbon) removal rate $(61 \%)$. An additional enhancement (up to $81 \%$ ) of the PAH removal rate was obtained by the addition of hydrogen peroxide during ozonation. Dogan and Sanin (2009) used a combined pretreatment method of alkaline solubilization (using $\mathrm{NaOH}$ ) and a relatively new technology of microwave (MW) irradiation $\left(160{ }^{\circ} \mathrm{C}\right)$ for sludge reduction. For combined pretreatments, they achieved soluble COD to total COD ratio (SCOD/TCOD) of waste activated sludge (WAS) increased from 0.005 (control) to $0.18,0.27,0.34$ and 0.37 for combined methods of MW and $\mathrm{pH} 10,11,12$ and 12.5 , respectively.

Integration of sludge pretreatment with aerobic biological treatment system is one of the interesting approaches in controlling excess sludge production. Pretreatment enhances the biodegradability of the sludge and its subsequent aerobic biodegradation demands more energy. However, integration of these two technologies reduces considerable energy savings as biodegradation occur at free of cost (Young et al. 2007) and improvement in nitrogen removal efficiency by the soluble organics in the pretreated sludge (Uan et al. 2009). Rocher et al. (2001) reported that it is possible for partial integration of sludge alkaline heat treatment loop in the conventional activated sludge processes. Sludge alkaline heat treatment allows the sludge production yield to be decreased significantly due to the biomass solubilization by the alkaline heat treatment and the cryptic growth occurring in the bioreactor (Rocher et al. 2001). Introduction of pretreated sludge into other wastewater treatment processes such as the AAO reactor may also be an interesting approach.

The objectives of this study were to investigate the effect of thermochemical sludge pretreatment on the excess sludge reduction and wastewater treatment performances in a lab-scale AAO reactor. The temperature used in the study was $60{ }^{\circ} \mathrm{C}$ for $3 \mathrm{~h}$ at $\mathrm{pH} 11$ for thermochemical pretreatment of sludge.

\section{Materials and methods}

\section{Experimental setup}

The experimental system contained AAO basins with working volumes of 1.5, 3.75, and 4.751 , respectively (Fig. 1). The hydraulic retention time (HRT) of AAO basin was 1.6, 4.2 and $5.3 \mathrm{~h}$, respectively. In the anaerobic basin, 200 polyurethane foam (PUF) cubes $(1 \mathrm{~cm} \times 1 \mathrm{~cm} \times 1 \mathrm{~cm})$ were used as carrier material. These floating carrier materials were kept inside the anaerobic basin by using a screen having ten holes (diameter of $1 \mathrm{~cm}$ ) to facilitate the transfer of mixed liquid to the anoxic basin. In order to facilitate nitrogen removal, the reactor was provided with the internal recycle (IR) between the aerobic and anoxic basins (IR1 $=250 \% Q$; with $Q=21.61 \mathrm{~d}^{-1}$ ). The second internal recycle (IR2) between the anaerobic and anoxic basins was maintained at $150 \% Q$. The low speed mixers were placed in the anaerobic and anoxic basins to keep the mixed liquor suspended solids (MLSS) in suspension. The dissolved oxygen (DO) of aerobic basin was 


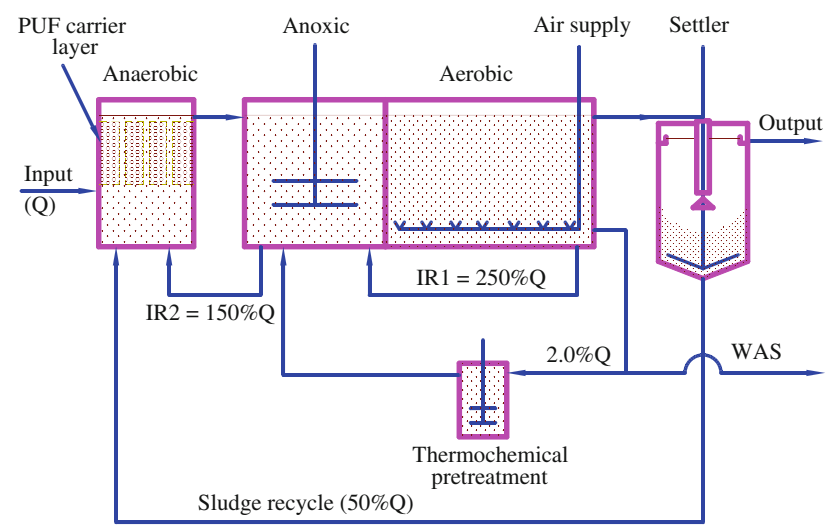

Fig. 1 Schematic diagram of AAO coupled with sludge pretreatment system

maintained in the range $2.0-4.0 \mathrm{mg} \mathrm{l}^{-1}$. The systems were operated for about 225 days of which 105 days were for system stability (Run 1). At Run 1, the solids retention time (SRT) of the system was maintained in the range 6.8-8.7 days. Sludge pretreatment was introduced into the anoxic basin (Run 2) on the 106th day. Introduction of pretreatment (Run 2) resulted in the increase of SRT to 13.5 days as solid concentrations in sludge wastage decrease considerably.

Synthetic domestic wastewater was used for the study. It was basically composed of a mixed carbon source, macronutrients ( $\mathrm{N}$ and $\mathrm{P})$, an alkalinity control $\left(\mathrm{NaHCO}_{3}\right)$ and a microelement solution (Rajesh et al. 2008). The composition contained $\left(\mathrm{l}^{-1}\right)$ macronutrient with $420 \mathrm{mg}$ glucose, $200 \mathrm{mg}$ $\mathrm{NH}_{4} \mathrm{Cl}, 220 \mathrm{mg} \mathrm{NaHCO} 3,22-34 \mathrm{mg} \mathrm{K \textrm {K } _ { 2 }} \mathrm{PO}_{4}$, microelement solution $\left(0.19 \mathrm{mg} \quad \mathrm{MnCl}_{2} \cdot 4 \mathrm{H}_{2} \mathrm{O}, \quad 0.0018 \mathrm{mg}\right.$ $\mathrm{ZnCl}_{2} \cdot 2 \mathrm{H}_{2} \mathrm{O}, 0.022 \mathrm{mg} \mathrm{CuCl} 2 \cdot 2 \mathrm{H}_{2} \mathrm{O}, 5.6 \mathrm{mg} \mathrm{MgSO}{ }_{4} \cdot 7 \mathrm{H}_{2} \mathrm{O}$, $0.88 \mathrm{mg} \mathrm{FeCl}{ }_{3} \cdot 6 \mathrm{H}_{2} \mathrm{O}, 1.3 \mathrm{mg} \mathrm{CaCl} 2 \cdot 2 \mathrm{H}_{2} \mathrm{O}$ ). The synthetic wastewater was prepared three times a week with concentrations of COD of $420 \pm 5 \mathrm{mg}^{-1}$, TN of $40 \pm 1 \mathrm{mg} \mathrm{l}^{-1}$ and TP of $5.0 \pm 0.1 \mathrm{mg} \mathrm{l}^{-1}$ with $\mathrm{pH} 6-7$.

The sludge from aerobic basin was withdrawn at a flow rate of $2 \% Q$. The $\mathrm{pH}$ of the sludge was 6.8 . The withdrawn sludge was taken in 51 batch reactor and its $\mathrm{pH}$ was adjusted to 11 using $1 \mathrm{~N}$ sodium hydroxide. The choice of this alkaline agent was made from different studies, which indicated that sodium hydroxide was more efficient than other alkaline agents in solubilising the sludge (Kim et al. 2003 and Lin et al. 2007).

After $\mathrm{pH}$ adjustment, the batch reactor was submersed in a thermostatic bath at $60{ }^{\circ} \mathrm{C}$ for $3 \mathrm{~h}$. During thermochemical pretreatment, the reactor was covered with an aluminum foil, to avoid water evaporation. The sludge in the reactor was kept in suspension by a slow speed stirrer (Digital Overhead IKA RW 20), to ensure temperature homogeneity.
Analytical methods

Samples for analysis of soluble constituents were filtered through a $0.45 \mu \mathrm{m}$ membrane filter (GD/X PVDF, Whatman). MLSS, mixed liquor volatile suspended solids (MLVSS), sludge volume index (SVI), chemical oxygen demand (COD), total phosphorous (TP), total nitrogen (TN) and nitrate $\left(\mathrm{NO}_{3}{ }^{-}\right)$were then determined on the filtrate obtained in accordance with standard methods (APHA 2005). The ammonia concentrations were measured using an ion-selective electrode (Thermo Orion, Model 95-12, Japan). $\mathrm{pH}$ and $\mathrm{DO}$ of the samples were measured with Horiba pH/DO meter (Model D-55E, Japan).

\section{Results and discussion}

Sludge disintegration and sludge reduction

The reactor was seeded with activated sludge taken from a pilot plant AAO reactor in Kehwang, South Korea. The MLSS concentrations in the system were maintained in the range of 2,500-3,500 $\mathrm{mg}^{-1}$ throughout the study. This was achieved by withdrawing $0.6-0.7 \mathrm{ld}^{-1}$ of excess sludge during Run 1, whereas during Run 2 , it was reduced to $0.2-0.3 \mathrm{l} \mathrm{d}^{-1}$, since sludge was reduced by thermochemical pretreatment (Fig. 2). The concentration of organics in mixed liquor was estimated in the form of MLVSS, and its corresponding concentration during the study period was in the range $2,100-2,800 \mathrm{mg} \mathrm{l}^{-1}$. The sludge produced in the system during the stable operation period of Run 1 was expressed in terms of the observed yields $\left(Y_{\mathrm{obs}}\right)$. The $Y_{\mathrm{obs}}$ was calculated by taking cumulative average of biomass produced divided by cumulative average of substrate consumed during stable operational period. The $Y_{\text {obs }}$ for Run 1 was found to be $0.27 \mathrm{~g}$ MLSS/g COD. In the present study the $\left(Y_{\text {obs }}\right)$ value was observed to be within the range 0.24-0.4, which is the typical $\left(Y_{\mathrm{obs}}\right)$ range for activated sludge treatment plants (Bolzonella et al. 2005). During Run 2, a part of the mixed liquor was withdrawn at the rate of $2.0 \% Q$ (about $0.44 \mathrm{l} \mathrm{d}^{-1}$ ) from the aerobic basin of AAO system and was pretreated by simultaneous thermochemical pretreatment at $60{ }^{\circ} \mathrm{C}$ and $\mathrm{pH} 11$. It is understandable that, an increase in pretreatment $Q$ of over $2 \%$ increases the percentage of sludge reduction. However, it is reported that an increase in the pretreatment of $Q$ of over $2 \%$ is not an economically viable option (Yan et al. 2009). Consequently, a pretreatment of $Q$ at 2 was maintained in the present study. Sodium hydroxide $(\mathrm{NaOH})$ was used to raise $\mathrm{pH}$ of the mixed liquor. The $\mathrm{pH}$ range of 11 was chosen mainly to maintain the $\mathrm{pH}$ level inside the aerobic basin near neutral. For example while working on sludge reduction using thermochemical treatment at $\mathrm{pH} 12$, 
Fig. 2 Variation of MLSS, MLVSS and VSS/SS ratio in the system

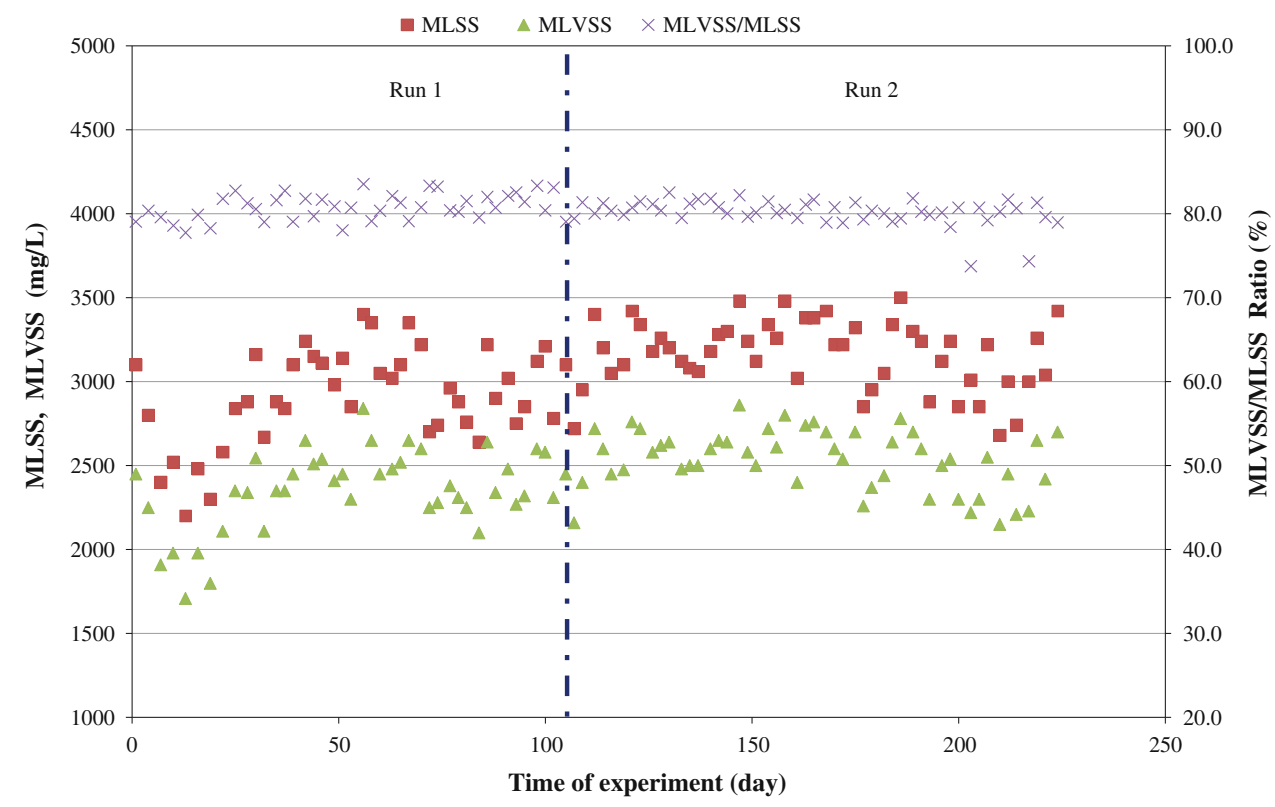

$\alpha=\frac{\mathrm{SCOD}-\mathrm{SCOD}_{\mathrm{o}}}{\mathrm{TCOD}-\mathrm{SCOD}_{\mathrm{o}}}$.

where $\mathrm{SCOD}_{\mathrm{o}}$ is the soluble $\mathrm{COD}$ of untreated sludge sample.

The observed values for the sludge disintegration experiments are also given in Fig. 3. The average solubilization efficiency for thermochemical treatment was found around 0.35 , which could be comparable with the values obtained from the thermal-alkali by others (Penaud et al. 1999; Neyens et al. 2003). Sludge reduction in a treatment system is achieved by combining sludge pretreatment along with subsequent biodegradation. In the present study, in order to facilitate the biodegradation of the pretreated sludge, it was recycled back into the AAO system, where subsequent biodegradation takes place. As a result of pretreated sludge recycling and its degradation, the daily sludge wastage was found to decrease from $0.59-0.70 \mathrm{l} \mathrm{d}^{-1}$ to $0.20-0.30 \mathrm{l} \mathrm{d}^{-1}$. At Run 2, $52 \%$ of sludge reduction was achieved with an observed yield of $0.13 \mathrm{~g} \mathrm{~g}^{-1}$ (gram of MLSS produced per gram of COD removed). The observed excess sludge reduction of $52 \%$ in this study was comparable with the $42 \%$ (Rajesh et al. 2011a) and also higher than the data (30 and $37 \%$ ) reported for activated treatment processes (Penaud et al. 1999; Rocher et al. 1999, 2001) and $60 \%$ (Rajesh et al. 2011b) reported for the aerobic treatment systems integrated with sludge pretreatment.

\section{Sludge characteristics}

The MLVSS/MLSS ratio plays an important role in governing the treatment efficiency of an aerobic treatment 
Fig. 3 Soluble COD and solubilization efficiency during sludge thermochemical digestion

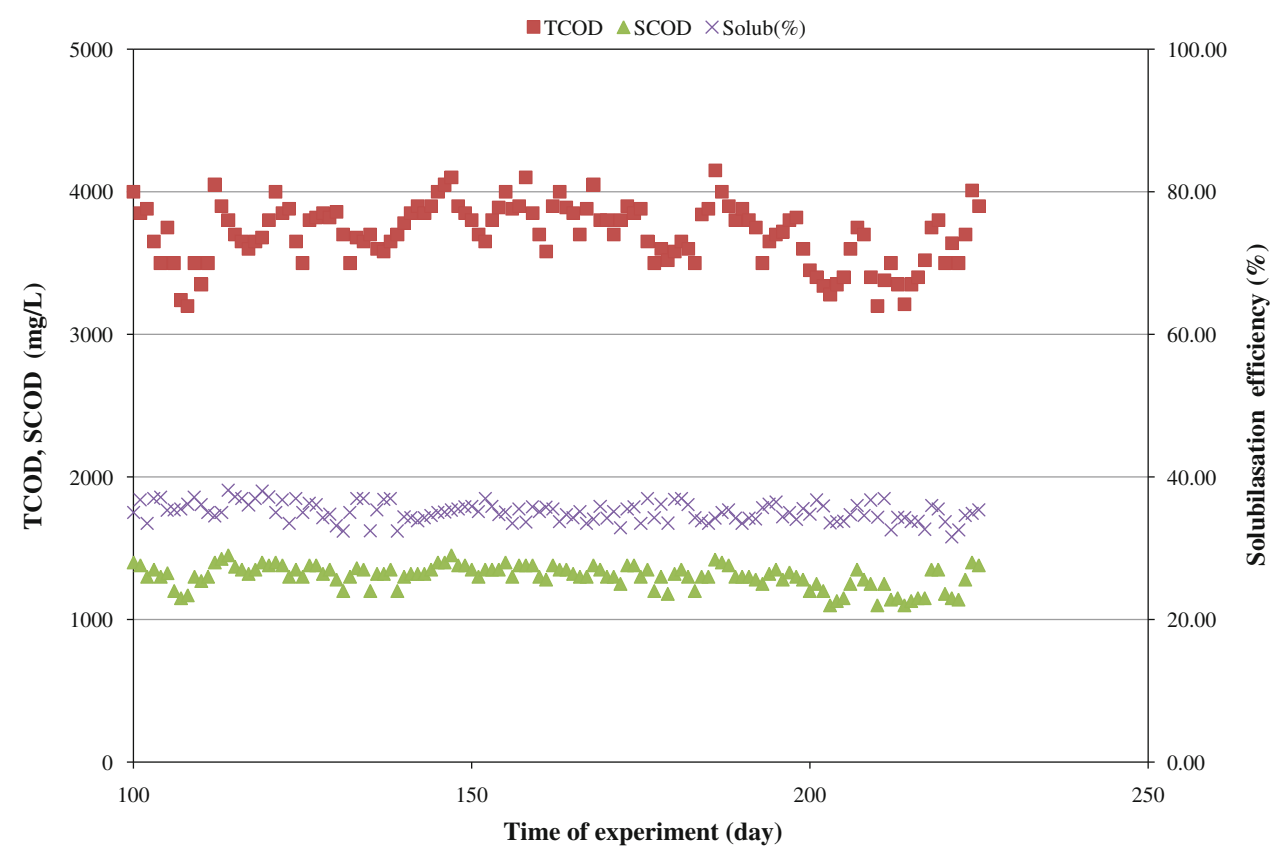

system. Any drastic decrease in this ratio affects the performance of the reactor (Rajesh et al. 2011a). One interesting observation of the present study is that the MLVSS/ MLSS ratios of two Runs were almost identical. The MLVSS/MLSS ratio was in the range 78-84 \% in Run 1 and $79-82 \%$ in Run 2 (Fig. 2). Previous work on sludge reduction with chemical pretreatment in aerobic treatment system by Young et al. (2007) reported no change in volatile fraction of the mixed liquor before and after the pretreatment. The results from the present study reveal that inorganics from the disintegrated cells do not accumulate in the reactor as insoluble inorganic particulates. The inorganic particulates might be taken out of the system by wasted sludge line or discharged along with the effluent. Similar to the present study, working on sludge reduction in AAO system treating domestic wastewater, Yan et al. (2009) and Rajesh et al. (2011a) have reported that there was no change in the MLVSS/MLSS ratio. Sludge volume index (SVI) of the mixed liquor plays an important role in settling of sludge (Metcalf and Eddy 2003). Poor settling of mixed liquor in clarifier leads to the decrease in treatment efficiency of a system (Metcalf and Eddy 2003). The monovalent cation like sodium often interferes with the settling characteristics of the sludge (Higgins and Novak 1997; Katja and Mika 2007). Due to this reason it was decided to compare the SVI of mixed liquor in Run 1 and Run 2 to verify whether sodium has any profound effect on SVI. The results revealed that there was no significant difference between the sludge volume indices in two Runs throughout the experimental operation (Fig. 4). It appears that the thermochemical sludge pretreatment using sodium hydroxide does not increase the SVI of the mixed liquor which presumably is a poor settling sludge. This may be due to the thermal effect, which on combination with alkali was found to improve the SVI of mixed liquor. From the present study, it is evident that simultaneous sludge pretreatment not only helps to improve the solubilization of sludge but also improves sludge quality.

\section{Effluent quality and performance of AAO}

Conventionally, biological nutrient removal was carried out in the AAO reactor; the success of its design depends upon its nitrogen and phosphorous removal efficiency from the wastewater (Shammas and Wang 2010). In the AAO system, nitrogen removal was carried out by recycling the mixed liquid containing nitrate into the anoxic basin through the internal recycle line. In anoxic basin, nitrate was reduced into nitrogen gas and removed from the system. The TN removal efficiency of the system is shown in Fig. 5. During Run 1, TN removal was in the range $68-75 \%$ and the corresponding $\mathrm{TN}$ concentration in the effluent was in the range $11-15 \mathrm{mg}^{-1}$, whereas in Run 2, TN removal efficiency was found to be $79-82 \%$ with effluent $\mathrm{TN}$ of $9-12 \mathrm{mg} \mathrm{l}^{-1}$. This slight increase in $\mathrm{TN}$ removal efficiency during Run 2 may be due to the external carbon source from pretreated sludge. This additional carbon may help to improve the denitrification by heterotrophic denitrifier. The $\mathrm{C} / \mathrm{N}$ ratio of the pretreated sludge solution was found to be in the range 11.5-13.5 (data not shown), which was significantly higher than the influent $\mathrm{C} / \mathrm{N}$ ratio (10.5). The introduction of the pretreated sludge into the system increased the influent $\mathrm{C} / \mathrm{N}$ ratio $1-3.5$. In other words, the addition of the external carbon source 
Fig. 4 Variation of SVI in the system

Fig. 5 Variation of TN, TP, COD and its removal efficiency in the system
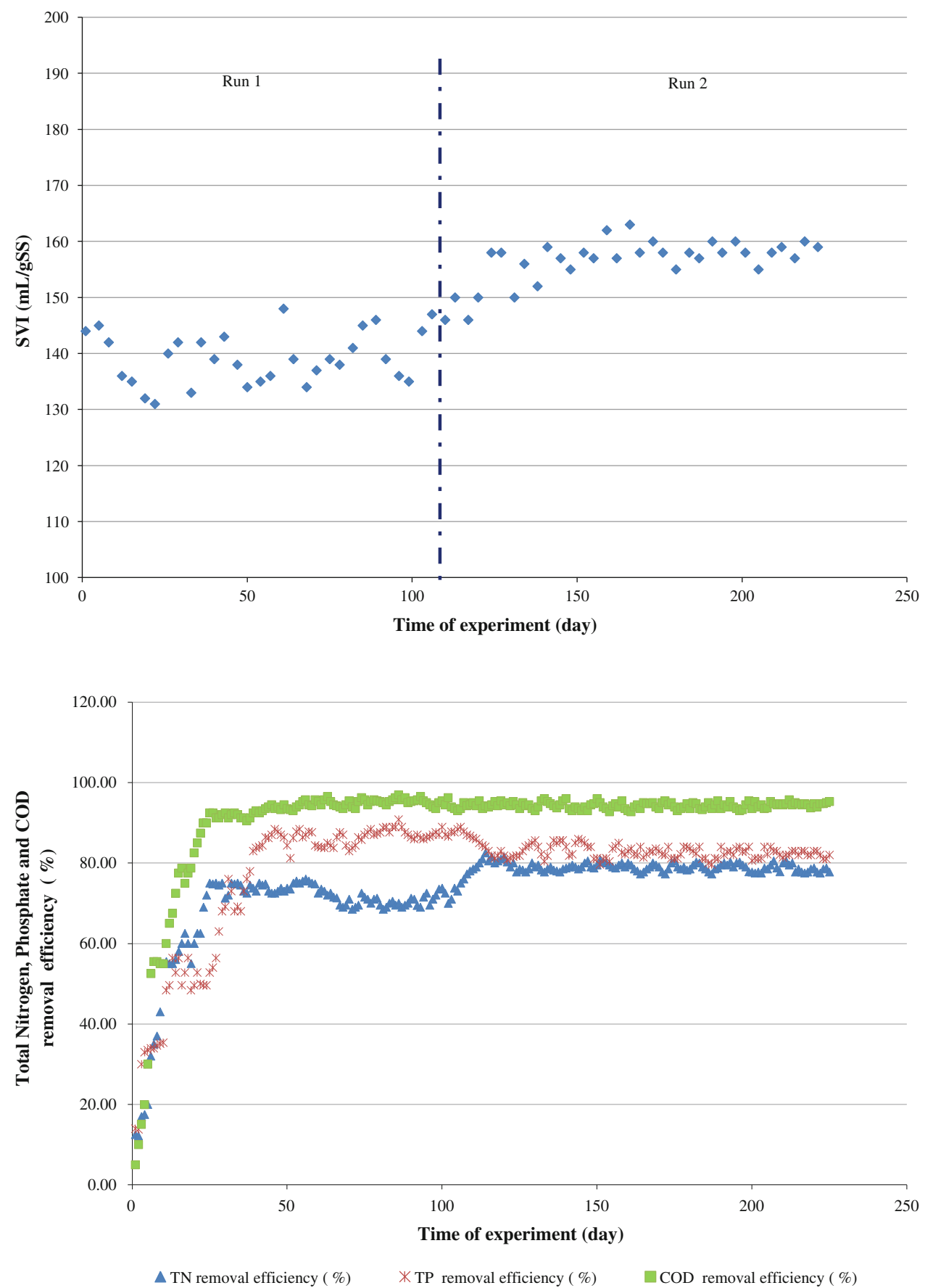

from pretreated sludge helped the denitrification process and subsequently improved the $\mathrm{TN}$ removal efficiency of the system.

The effluent TP concentrations during the operation are shown in Fig. 5. The effluent TP values varied between 0.5 and $0.8 \mathrm{mg} \mathrm{l}^{-1}$ in Run 1 and 0.7 and $0.9 \mathrm{mg}^{-1}$ in Run 2. The present study recorded high phosphorous removal efficiency when compared to other similar systems used to treat domestic wastewater (Rajesh et al. 2008; Yu and Zhou 2010). The improvement of phosphorous removal is likely due to the use of UCT-like recirculation which is beneficial for PAO organisms and subsequent phosphorous removal. Phosphorous removal efficiency of the system was found to be in the range 88-90\% and 80-84\% for Run 1 and Run 2, respectively. In Run 2, the solubilised phosphorous when returned into the system slightly increases phosphorous concentration in the effluent stream. Figure 5 shows the COD concentrations in the influent and the effluent of the system. The COD concentrations of the effluents were found to be in the range $12-25 \mathrm{mg} \mathrm{l}^{-1}$ with 
removal efficiency of $94 \%$ during Run 1 . In Run 2, the excess sludge was disintegrated and returned to the system as feed organics. Based on previous reports, increase in OLR was due to the return of pretreated sludge, which caused decrease in COD removal performance (Yasui and Shibata 1994; Yasui et al. 1996). However, the results from this study indicated that the presence of sludge disintegration period did not have significant impacts on the effluent COD values.

\section{Conclusion}

Reduction of sludge production in a lab-scale AAO combined sludge pretreatment appears to be an alternative solution for sludge disposal. The present study showed that association of thermochemical sludge pretreatment along with the AAO system proved its high efficiency and reliability. A high reduction of sludge production (52\%) can be obtained when a part of the waste activated sludge ( $2 \%$ of the influent flow rate) is disintegrated through thermochemical treatment at $\mathrm{pH} 11$ and $60{ }^{\circ} \mathrm{C}$ for $3 \mathrm{~h}$. An average solubilization efficiency of $35 \%$ could be achieved. It appears that the solubilized fraction of the mixed liquor obtained by the thermochemical sludge pretreatment might be easily biodegraded by other microorganisms. No significant accumulation of inorganic substances was observed. It was found that introduction of pretreated sludge into the anoxic tank had no significant effect on nutrient removal.

Acknowledgments This study was supported by the Brain Korea 21 (BK-21) program from Korean Ministry of Education, Science and Technology. The authors would also like to thank the partial supports of the Basic Science Research Program through the National Research Foundation of Korea (NRF) (Grant number: 2010-0008860).

\section{References}

APHA (2005) Standard methods for the examination of water and wastewater. 21st edition, American Public Health Association, Washington

Bernal-Martinez A, Carrere H, Patureau D, Delgenes JP (2005) Combining anaerobic digestion and ozonation to remove PAH from urban sludge. Process Biochem 40:3244-3250

Bolzonella D, Pavan P, Battistoni P, Cecchi F (2005) Mesophilic anaerobic digestion of waste activated sludge: influence of the solid retention time in the wastewater treatment process. Process Biochem 40:1453-1460

Carballa M, Omil F, Alder AC, Lema JM (2006) Comparison between the conventional anaerobic digestion of sewage sludge and its combination with a chemical or thermal pre-treatment concerning the removal of pharmaceuticals and personal care products. Water Sci Technol 53(8):109-117

Climent M, Ferrer I, Mar Baeza MD, Artola A, Vazquez F, Font X (2007) Effects of thermal and mechanical pretreatments of secondary sludge on biogas production under thermophilic conditions. Chem Eng J 133:335-342
Davis RD, Hall JE (1997) Production, treatment and disposal of wastewater sludge in Europe from a UK perspective. Eur Water Pollut Contr 7:9-17

Dogan I, Sanin DF (2009) Alkaline solubilization and microwave irradiation as a combined sludge disintegration and minimization method. Water Res 43:2139-2148

Erdincler A, Vesilind PA (2000) Effect of sludge cell disruption on compactibility of biological sludge. Water Sci Technol 42(9): $119-126$

Eskicioglu C, Kennedy KJ, Droste RL (2008) Initial examination of microwave pretreatment on primary, secondary and mixed sludges before and after anaerobic digestion. Water Sci Technol 57(3):311-317

Gavala HN, Yenal U, Skiadas IV, Westermann P, Ahring BK (2003) Mesophilic and thermophilic anaerobic digestion of primary and secondary sludge. Effect of pre-treatment at elevate temperature. Water Res 37:4561-4572

Higgins MJ, Novak JT (1997) The effect of cations on the settling and deatering of activated sludges: laboratory experience. Water Environ Res 69:215-224

Katja H, Mika S (2007) Flocculation in paper and pulp mill sludge process. Res J chem Environ 11(3):96-103

Kim J, Park C, Kim TH, Lee M, Kim S, Kim SW, Lee J (2003) Effects of various pretreatments for enhanced anaerobic digestion with waste activated sludge. J Biosci Bioeng 95(3):271-275

Lee SI, Weon SY, Lee CW, Koopman B (2003) Removal of nitrogen and phosphate from wastewater by addition of bittern. Chemosphere 51:265-271

Li H, Jin YY, Mahar RB, Wang ZY, Nie YF (2009) Effects of ultrasonic disintegration on sludge microbial activity and dewaterability. J Hazard Mater 161(2-3):1421-1426

Lin JG, Chang CN, Chang SC (2007) Enhancement of anaerobic digestion of waste activated sludge by alkaline solubilization. Bioresour Technol 62:85-90

Liu Y, Tay JH (2001) Strategy for minimization of excess sludge production from the activated sludge process. Biotechnol Adv 19:97-107

Ma Y, Peng YZ, Wang XL, Wang SY (2005) Nutrient removal performance of $\mathrm{A} 2 \mathrm{O}$ process as a function of influent $\mathrm{C} / \mathrm{P}$ ratio. J Chem Technol Biotechnol 80:1118-1124

Metcalf and Eddy (2003) Wastewater engineering: treatment, disposal and reuse, 4th edn. McGraw-Hill, New York

Muller JA (2000) Pretreatment processes for the recycling and reuse of sewage sludge. Water Sci Technol 42:167-174

Müller JA (2001) Prospects and problems of sludge pre-treatment processes. Water Sci Technol 4:121-128

Navia R, Soto M, Vidal G, Bornhardt C, Diez MC (2002) Alkaline pretreatment of kraft mill sludge to improve its anaerobic digestion. Bull Environ Contam Toxicol 69(6):869-876

Neyens E, Baeyens J, Creemers C (2003) Alkaline thermal sludge hydrolysis. J Hazard Mater 97:295-314

Neyens E, Baeyens J, Dewil R, De Heyder B (2004) Advanced sludge treatment affects extracellular polymeric substances to improve activated sludge dewatering. J Hazard Mater 106(2-3): $83-92$

Novelli A, Ottonello F, Converti A, Lodi A, Rovatti M, Del Borghi M (1995) Alkaline hydrolysis for the treatment of the organic fraction of municipal solid wastes and sludges. Chem Biochem Eng Q 9:195-199

Oh YK, Lee KR, Ko KB, Yeom IT (2007) Effects of chemical sludge disintegration on the performances of wastewater treatment by membrane bioreactor. Water Res 41:2665-2671

Penaud V, Delgenes JP, Moletta R (1999) Thermo-chemical pretreatment of a microbial biomass: influence of sodium hydroxide addition on solubilization and anaerobic biodegradability. Enzyme Microb Tech 25:258-263 
Pinnekamp J (1989) Effects of thermal pretreatment of sewage sludge on anaerobic digestion. Water Sci Technol 21:97-108

Rajan RV, Lin JG, Ray BT (1989) Low-level chemical pretreatment for enhanced sludge solubilization. J Water Pollut Contr Fed 61(11-12):1678-1683

Rajesh BJ, Do KU, Yeom IT (2008) Effect of ferrous slulphate on nitrification during simultaneous phosphorous removal. World J Microbiol Biotechnol 24:2981-2986

Rajesh BJ, Uan Do Khac, Kaliappan S, Yeom IT (2011a) Effect of sludge pretreatment on the performance of anaerobic/anoxic/ oxic membrane bioreactor treating domestic wastewater. Int $\mathbf{J}$ Environ Sci Tech 8(2):281-290

Rajesh BJ, Hac-Uan Do, Kumar Athish, Yeom IT (2011b) Effect of low temperature thermochemical pretreatment on sludge reduction capacity of MBR treating secondary treated dairy wastewater. Water Qual Res J Can 46(4):312-320

Rajesh BJ, Do KU, Adish KS, Yeom IT (2012) A novel method of sludge pretreatment using the combination of alkalis. J Environ Biol 33:249-253

Ray BT, Lin JG, Rajan RV (1990) Low-level alkaline solubilization for enhanced anaerobic digestion. J Water Pollut Contr Fed 62:81-87

Rocher M, Goma G, Pilas GA, Louvel L, Rolls JL (1999) Towards a reduction in excess sludge production in activated sludge processes: biomass physicochemical treatment and biodegradation. Appl Microbiol Biotechnol 51:883-890

Rocher M, Roux G, Goma G, Begue AP, Louvel L, Rolls JL (2001) Excess sludge reduction in activated sludge reduction in activated sludge processes by integrating biomass alkaline heat treatment. Water Sci Technol 44:437-444

Salsabil MR, Prorot A, Casellas M, Dagot C (2009) Pre-treatment of activated sludge: effect of sonication on aerobic and anaerobic digestibility. Chem Eng J 148(2-3):327-335

Shammas NK, Wang LK (2010) A/O phosphorus removal biotechnology. Environ Biotechnol 10:783-814

Spellman FR (1997) Wastewater biosolids to compost. Technomic Publishing Company, Lancaster, pp 223-235
Stuckey DC, McCarty PL (1984) The effect of thermal pretreatment on the anaerobic biodegradability and toxicity of waste activated sludge. Water Res 18(11):1343-1353

Tanaka S, Kobayashi T, Kamiyama K, Signey Bildan MLN (1997) Effects of thermochemical pretreatment on the anaerobic digestion of waste activated sludge. Water Sci Technol 35:209-215

Uan DK, Rajesh BJ, Yeom IT (2009) Effect of thermochemical treatment on sludge reduction and the performance of anoxicoxic membrane bioreactor treating domestic wastewater. J Chem Tech Biotech 84(9):1350-1355

Uma R, Athish Kumar S, Yeom IT, Rajesh BJ (2012) Low temperature thermochemical pretreatment of dairy WAS for anaerobic digestion process. Bioresour Technol 103(1):415-424

Wilson CA, Novak JT (2009) Hydrolysis of macromolecular components of primary and secondary wastewater sludge by thermal hydrolytic pretreatment. Water Res 43:4489-4498

Yan ST, Chub LB, Xing XH, Yu AF, Sun XL, Jurcik B (2009) Analysis of the mechanism of sludge ozonation by a combination of biological and chemical approaches. Water Res 43:195-203

Yasui H, Shibata M (1994) An innovative approach to reduce excess sludge production in the activated sludge process. Water Sci Technol 30(9):11-20

Yasui H, Nakamura K, Sakuma S, Iwasaki M, Sakai Y (1996) A fullscale operation of a novel activated sludge process without excess sludge production. Water Sci Technol 34:395-404

Yeom IT, Lee KR, Choi YG (2005) A pilot study on accelerated sludge degradation by a high-concentration membrane bioreactor coupled with sludge pretreatment. Water Sci Technol 52:201-210

Yeoman S, Stephenson T, Lester JN, Perry R (1988) The removal of phosphorus during wastewater treatment: a review. Environ Pollut 49:183-233

Young KO, Lee KR, Kwang BK, Yeom IT (2007) Effects of chemical sludge disintegration on the performances of wastewater treatment by membrane bioreactor. Water Res 41(12):2665-2671

Yu J, Zhou S (2010) Nitrogen removal efficiency of an A2/O bioreactor treating domestic sewage mixed with landfill leachate and fecal sewage. Global NEST J 12(2):181-189 